\title{
Effect of eutrophication on culm architecture of lakeshore Phragmites reeds
}

\author{
Wolfgang Ostendorp ${ }^{\mathrm{a}, *}$, Eva Tiedge ${ }^{\mathrm{a}}$, Sven Hille ${ }^{\mathrm{b}}$ \\ ${ }^{a}$ Limnologisches Institut, Universität Konstanz, D-78457 Konstanz, Germany \\ ${ }^{\mathrm{b}}$ Botanisches Institut, Universität Greifswald, D-17487 Greifswald, Germany
}

\begin{abstract}
The eutrophication of lakes in central Europe has been assumed to be at least partly responsible for a widespread die-back of fringing Phragmites australis reeds. To test the 'eutrophication hypothesis' on a broad data basis, lakeshore reed stands at 41 lakes of known trophic status and 10 stands in waste water and sludge treatment plants in Denmark and north Germany (North data subset, $n=26$ ), and south Germany, Switzerland and Austria (South data subset, $n=25$ ) were investigated. A total of 24 culm performance variables in three different shoot classes were analyzed by two-way ANOVA with the geographic origin and the 'relative trophic index' as factors. The geographic origin had a pronounced influence on culm architecture, whereas the effect of the trophic level mostly failed to be significant in the ANOVA. The culms from the North reed stands showed a weaker performance throughout than those from the South stands for a given trophic level. However, some of the morphometric traits in the North stands were significant positively correlated with the trophic level but very few significant cases were observed in the South data subset. Three hypotheses are discussed to explain the geographic effect: climatic effects, geochemistry of lake water and sediments, and trophic history of the lakes. It is concluded that lake eutrophication does not influence the culm performance negatively and that eutrophication cannot be regarded as a general cause in reed decline. (C) 2001 Elsevier Science B.V. All rights reserved.
\end{abstract}

Keywords: Reed die-back; Littoral zone; Stand structure of reeds; EUREED; Phragmites australis

\section{Introduction}

More than 50 lakes in central Europe are affected by an extensive decline of fringing Phragmites reeds (Ostendorp, 1989). The debate on the significance of specific causal factors is just continuing, comprising direct destruction, mechanical damage by waves and drifting matter, grazing by phytophagous arthropods, waterfowl and herbivorous mammals, extreme

\footnotetext{
* Corresponding author. Fax: +49-7531-883533.

E-mail address: wolfgang.ostendorp@uni-konstanz.de (W. Ostendorp).
} 


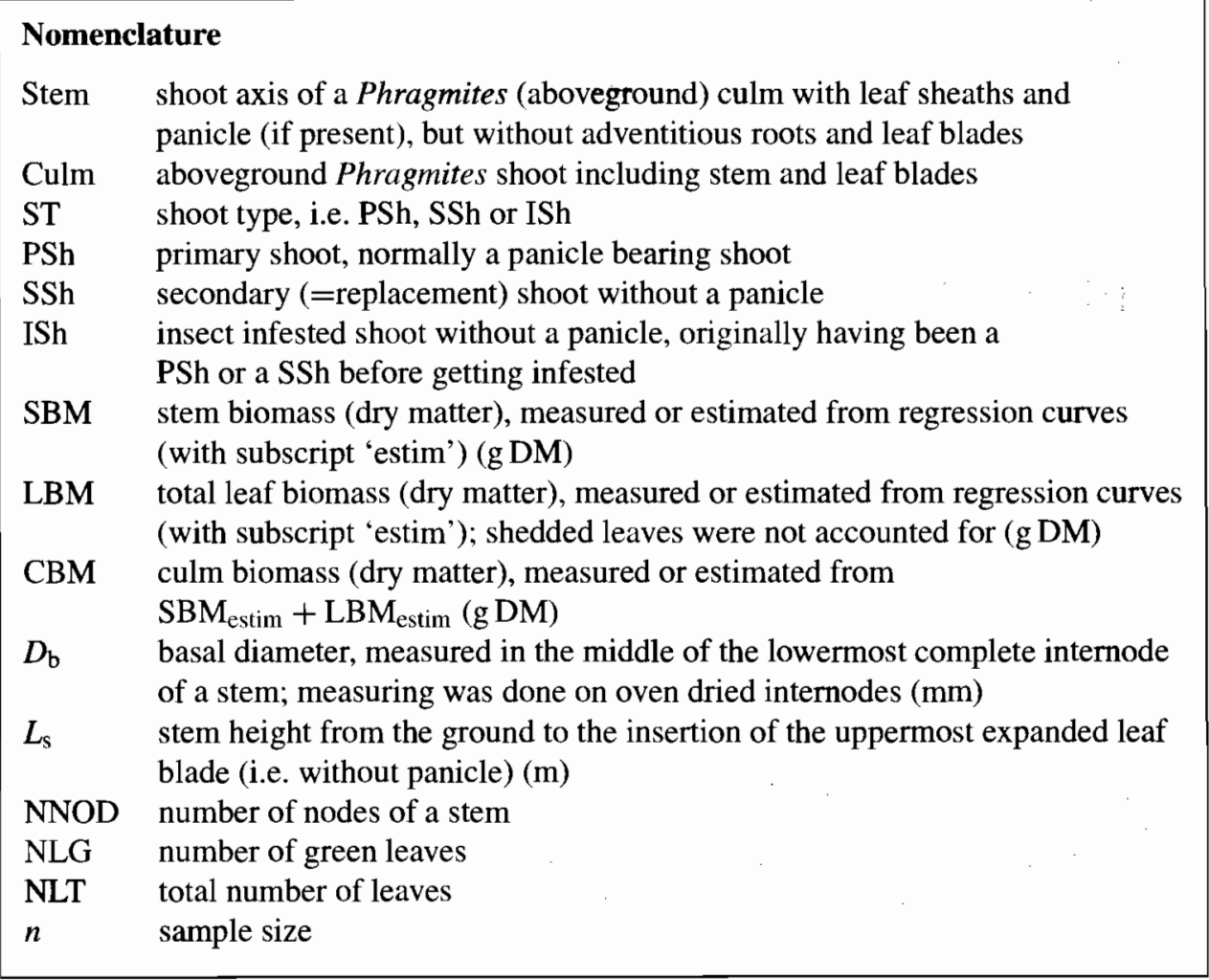

water table fluctuations followed by bank erosion, and several facets of lake eutrophication. Klötzli (1971) and Schröder $(1979,1987)$ were the first to put forward what was later called the 'eutrophication hypothesis' of reed die-back. They argued that the growing availability of nitrogen and phosphorus would increase the shoot density and reduce the mechanical stability of the culm. The enhanced biomass production was thought to lead to a 'matting' of these overfertilized reed crops resulting in organic matter accumulation in the sediments. This would be followed by oxygen depletion in the sediment/water interface, accumulation of phytotoxins and remobilization of nutrients from the sediments which in turn would exacerbate the effects of pelagic eutrophication.

Much work has been done since that time, mostly within the EUREED I and II projects, on specific issues at some 'die-back' and 'healthy' stands (for reviews see Van der Putten, 1994; Brix, 1999a,b). However, the question remained unanswered whether reed stands are in general affected by the trophic level of lakes with respect to their morphological and structural features, tissue nutrient content and biomass production. Additionally, it remained unclear whether there are trends, following the trophic scale, which may be interpreted as deterioration indices indicating serious stresses to the reeds, which again may finally lead to a die-back.

In this study, the effect of the pelagic eutrophication on culm morphology of Phragmites reeds was investigated analyzing 41 Phragmites stands at oligotrophic, mesotrophic, 
eutrophic and hyper-/polytrophic lakes and 10 saprotrophic stands in waste water or sludge treatment plants through central Europe. The objective was to evolve significant relations between culm morphology traits and the trophic level, to look for 'deterioration indices', especially at higher levels of nutrient load.

\section{Materials and methods}

\subsection{Sampling locations}

A large body of scientific papers, reports from water and environment protection authorities as well as unpublished data collections were examined prior to selecting 51 locations for sampling. The set of sampling sites covered the full range of trophic conditions from oligotrophic over hyper-/polytrophic lakes to saprotrophic artificial wetlands. About 26 locations were located in Denmark and northern Germany (North data subset), another 25 sites came from southern Germany, Switzerland and Austria (South data subset) (Fig. 1). Criteria for selection were the presence of a well developed reed belt, the availability of limnochemical data and precise site descriptions, together with logistic considerations (accessibility by car or boat, etc.). In case of constructed wetlands, it was ensured that they received only municipal waste water or pretreated waste water sludge. Furthermore, that the plantation was older than 4 years. A complete list of sampling sites is given in Appendix.

\subsection{Sampling and morphometric measurements}

Sampling took place in the second half of August and in the first days of September 1997, when the Phragmites culms normally are fully developed and the panicles are ripe. The southern sites were sampled ca. 10 days earlier than the northern sites to compensate for the delay of ontogeny of northern culms due to climatic differences. At each lake, an ordinary reed belt, not damaged by human activities or by wave and drifting matter action, not harvested in previous winter and without any sign of die-back was selected at a lee-sided shore section avoiding small sheltered bights, spits or headlands, and other singularities like landing places, water inlets, bow net constructions, etc. Phragmites stands on deep peaty soils were omitted. About $5-8$ sampling quadrats of $0.24-1 \mathrm{~m}^{2}$ each were randomly chosen, ca. 3-10 $\mathrm{m}$ apart from the lakeside reed belt edge to prevent edge effects. In constructed wetlands, sampling took place in the center or near the outlet, according to the available water quality data. Culm numbers in the quadrats were counted, recording also the shoot type, i.e. primary, secondary, and insect infested shoots (PSh, SSh, ISh). About 10 PSh, ca. $5 \mathrm{SSh}$, and ca. 5 ISh were chosen randomly, clipped off at ground level and processed in the field camp within $24 \mathrm{~h}$. The measured variables included culm length, panicle length, total and green leaf number, and basal diameter.

\subsection{Culm biomass estimation}

At each location, ca. seven culms were used for gravimetric biomass measurements. The biomass was separated into stem (including leaf sheaths), leaves and panicle. The 


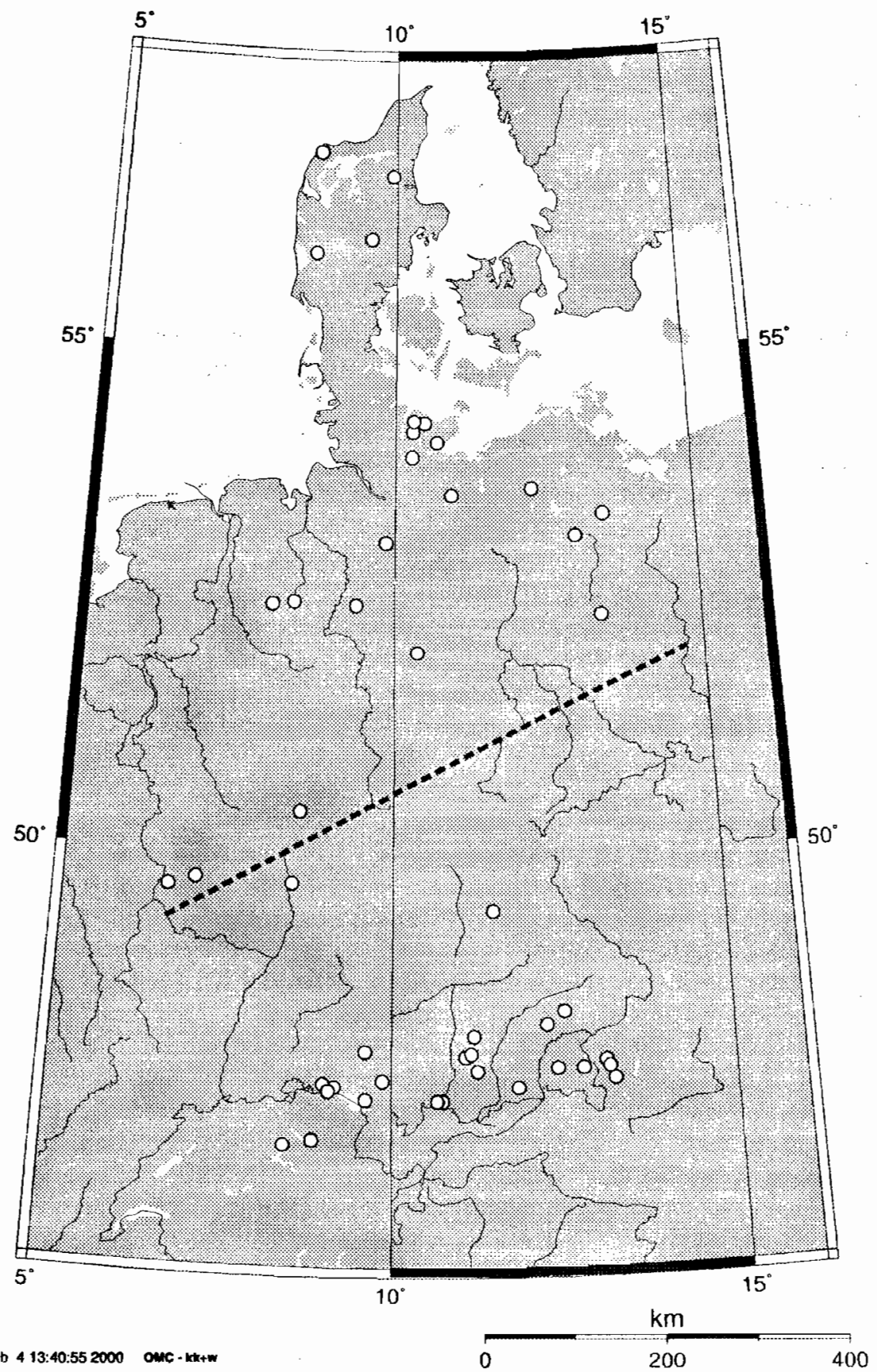

Fig. 1. Location of sampling sites. The dashed line separates the North and the South data subsets. See Appendix for further details. 
components were dried at $80^{\circ} \mathrm{C}$ to constant weight. These data were used to calculate the parameters of biomass calibration functions. The biomass values of the remaining culms were calculated from these regression models. For definitions see Nomenclature.

The individual stem biomass (SBM) including the panicle biomass, if present, was estimated using the cylinder model

$$
\mathrm{SBM}=a D_{\mathrm{b}}^{b} L_{\mathrm{s}}^{c}
$$

with the basal diameter $D_{\mathrm{b}}$ and the stem height $L_{\mathrm{s}}$ as input variables. The coefficients $a, b$, and $c$ were estimated by linear multiple regression of the linearized model

$$
\log \mathrm{SBM}=\log a+b \log D_{\mathrm{b}}+c \log L_{\mathrm{s}}
$$

The biomass values of PSh, SSh and ISh were estimated sephately. The leaf biomass (LBM) was calculated from a second-order polynomial model

$$
\mathrm{LBM}=a \mathrm{SBM}_{\mathrm{estim}}+b \mathrm{SBM}_{\mathrm{estim}}^{2}
$$

where SBM $_{\text {estim }}$ is the estimated stem biomass according to (Eq. (1)). A no-intercept model was applied since it fitted the total leaf weight of small shoots better than any intercept model. The coefficients of determination $R^{\prime 2}$ were computed from the linear correlation $\mathrm{LBM}_{\text {estim }}$ versus $\mathrm{LBM}_{\text {measured }}$.

The total culm biomass, CBM, including leaves, leaf sheaths, and panicle if present, was calculated as

$$
\mathrm{CBM}=\mathrm{SBM}+\mathrm{LBM}
$$

In these estimates, shedded leaves were not accounted for.

\subsection{Data evaluation}

The model included two independent variables: the geographic origin (GEO, i.e. North and South), and the 'relative trophic index' (RTI). The RTI was calculated using the same limnochemical data as in the trophic models of Vollenweider (1971) and LAWA (1998), i.e. the concentrations of

- total phosphorus: (i) spring turnover means, (ii) yearly means; total water column, (iii) summer means; epilimnic water column;

- chlorophyll a: (i) yearly means, (ii) summer means, (iii) yearly maximum; epilimnic water column;

- secchi depth: (i) yearly means, (ii) summer means.

For the saprotrophic sites, only the yearly and the summer means of the total phosphorus from the inlets and/or outlets were applied. The concentrations of nitrogen species were not included, following thereby the conception of Vollenweider (1971); LAWA (1998). The data were tested for normality. The $\mathbf{P}$ and 'chlorophyll a' concentrations had to be $\log _{10}$ transformed to yield normal distributions. The data matrix contained $9 \%$ missing values which were filled up by estimates from multiple regressions in which all other limnochemical 
data were independent variables. The limnochemical variables were standardized to zero mean and unit variance over the sample, i.e. 51 locations. Finally, the mean standardized value over all variables (i.e. eight for lakes, and two for artificial wetlands) was calculated to get the RTI for an individual location.

The culm morphology variables were tested for normality and when necessary suitable transformations were made. The effects of GEO and RTI on these variables were analyzed by two-way ANOVA and by linear regression models. The statistical evaluation was done with $\mathrm{JMP}^{\circledR}$ version 3.2.1 (SAS Institute Inc.).

\section{Results}

\subsection{Relative trophic index (RTI)}

The RTI was found to be in good agreement with the trophic categories as derived from the Vollenweider and the LAWA model. Most differences of RTI means among the categories were highly significant (Table 1).

\subsection{Biomass estimation}

The parameter estimates for the PSh biomass based on a total of 152 culms usually three from each location: one short, one tall and one culm of medium size. $D_{\mathrm{b}}$ and $L_{\mathrm{s}}$ were introduced in logarithmic form in the regression model

$$
\log \mathrm{SBM}=-0.227+1.101 \log D_{\mathrm{b}}+1.437 \log L_{\mathrm{s}}, R^{2}=0.902
$$

The stem morphometry and biomass of SSh relied on 96 culms, usually two, a stout one and a weak one, from each location. The same model was applied as for the PSh

$$
\log \mathrm{SBM}=-0.405+1.283 \log D_{\mathrm{b}}+1.207 \log L_{\mathrm{s}}, R^{2}=0.917
$$

The ISh culm class (a total of 90 culms) comprised different types of insect damage. All damage types were pooled since no significant effect of damage type on SBM was detected.

Table 1

Relation between trophic categories (see Vollenweider, 1971; LAWA, 1998) and relative trophic index (RTI) (means \pm standard deviation (S.D.) $)^{\mathrm{a}}$

\begin{tabular}{lcccc}
\hline Trophic category & Sample size & RTI (mean \pm S.D.) & Minimum & Maximum \\
\hline Oligotrophic & 4 & $-1.20 \pm 0.22$ & -1.50 & -1.02 \\
Oligo-/mesotrophic & 4 & $-0.88 \pm 0.26$ & -1.23 & -0.65 \\
Mesotrophic & 15 & $-0.53 \pm 0.21$ & -1.02 & -0.14 \\
Eutrophic & 10 & $0.18 \pm 0.21$ & -0.06 & 0.56 \\
Poly-/hypertrophic & 8 & $1.06 \pm 0.20$ & 0.81 & 1.34 \\
Saprotrophic & 10 & $1.75 \pm 0.45$ & 0.92 & 2.41 \\
\hline
\end{tabular}

a See Appendix for details. Trophic categories were adopted from the local investigators or estimated applying the models of Vollenweider (1971); LAWA (1998). Means of all pairs are significantly different at $P<0.01$ except oligo-/mesotrophic vs. oligotrophic and vs. mesotrophic, respectively (Tukey-Kramer's HSD test). 
The model fit

$$
\log \mathrm{SBM}=-0.343+1.422 \log D_{\mathrm{b}}+1.005 \log L_{\mathrm{s}}, R^{2}=0.867
$$

was yielded for the data set.

Each parameter in Eqs. (5-7) was significantly different from zero at the $P=0.0001$ level. The influence of $D_{\mathrm{b}}$ on SBM was lower than the influence of $L_{\mathrm{s}}$ in PSh and SSh, when regarding the standardized coefficients $\left(\beta\right.$-values) $\beta\left(\log D_{\mathrm{b}}\right)=0.42-0.45, \beta\left(\log L_{\mathrm{s}}\right)=$ $0.55-0.58$ but the contrary was true for ISh $\left(\beta\left(\log D_{\mathrm{b}}\right)=0.61, \beta\left(\log L_{\mathrm{s}}\right)=0.40\right)$. There was, however, a high colinearity between $D_{\mathrm{b}}$ and $L_{\mathrm{s}}: 34-60 \%$ of the $L_{\mathrm{s}}$ variability could be explained by its dependence on $D_{\mathrm{b}}$, and vice versa.

The parameters of the total leaf biomass LBM were estimated on the same data basis as for stem biomass estimation. The regressions

$$
\begin{array}{ll}
\text { PSh : } & \text { LBM }=0.394 \mathrm{SBM}_{\text {estim }}-0.00260 \mathrm{SBM}_{\text {estim }}^{2}, R^{\prime 2}=0.718 \\
\text { SSh : } & \text { LBM }=0.534 \mathrm{SMB}_{\text {estim }}-0.01023 \mathrm{SBM}_{\text {estim }}^{2}, R^{\prime 2}=0.716
\end{array}
$$

fitted the data of the PSh and the SSh class, respectively. Both parameters were significant at the $P=0.0001$ level. For the polygenetic ISh, no significant influence of the damage type on the regression curve could be detected. Therefore, all groups were pooled, yielding a single regression curve

$$
\mathrm{LBM}=0.385 \mathrm{SMB}_{\text {estim }}-0.00246 \mathrm{SBM}_{\text {estim }}^{2}, R^{\prime 2}=0.694
$$

Both, the parameter of the linear increase and the parameter of the curvature were significantly different from zero $(P<0.0001$, and $P=0.008$, respectively).

The influences of GEO and RTI on the regressions were tested with a full factorial ANOVA (data not shown). Any significant first-order interaction with $D_{\mathrm{b}}, L_{\mathrm{s}}$ or $\mathrm{SBM}_{\mathrm{estim}}$ (see Eqs. (5-10)) and GEO, as well as RTI could be detected, except for ISh. Here, the regression $\log \mathrm{SBM}=\log \mathrm{SBM}\left(\log D_{\mathrm{b}} ; \log L_{\mathrm{S}}\right)$ was weakly effected by the RTI $(P=0.04)$.

\subsection{Regression of culm morphometry features on basal diameter}

Stem height, $L_{\mathrm{s}}$, number of nodes, NNOD, number of green leaves, NGL, and total leaf number, NTL, of Phragmites culms were closely related to the basal diameter, $D_{\mathrm{b}}$, in the whole data set $(n=971-981)$. There were also significant effects of the shoot type (ST) for all variables (Table 2). The $D_{\mathrm{b}} \times \mathrm{ST}$ interactions were significant throughout, demonstrating that the slope of the regression lines with $D_{\mathrm{b}}$ differed among stem types. The ISh showed a lower culm length, a lower number of nodes and green leaves, and also a lower total leaf number compared with the PSh and the SSh for any basal diameter given (Fig. 2). The estimates for the regression coefficients were higher in SSh than in PSh and in ISh (Table 2). Hence, the response of $L_{\mathrm{s}}$, NNOD, NGL and NTL to an increase in stem diameter is much stronger in secondary shoots than in the other culm classes.

The influence of geographic origin and trophic level was analyzed by a full factorial three-way ANOVA with RTI and GEO as factors, and sqrt-transformed $D_{\mathrm{b}}$ as a covariate (data not shown). No significant RTI $\times D_{\mathrm{b}}$ and GEO $\times D_{\mathrm{b}}$ interactions could be detected for 


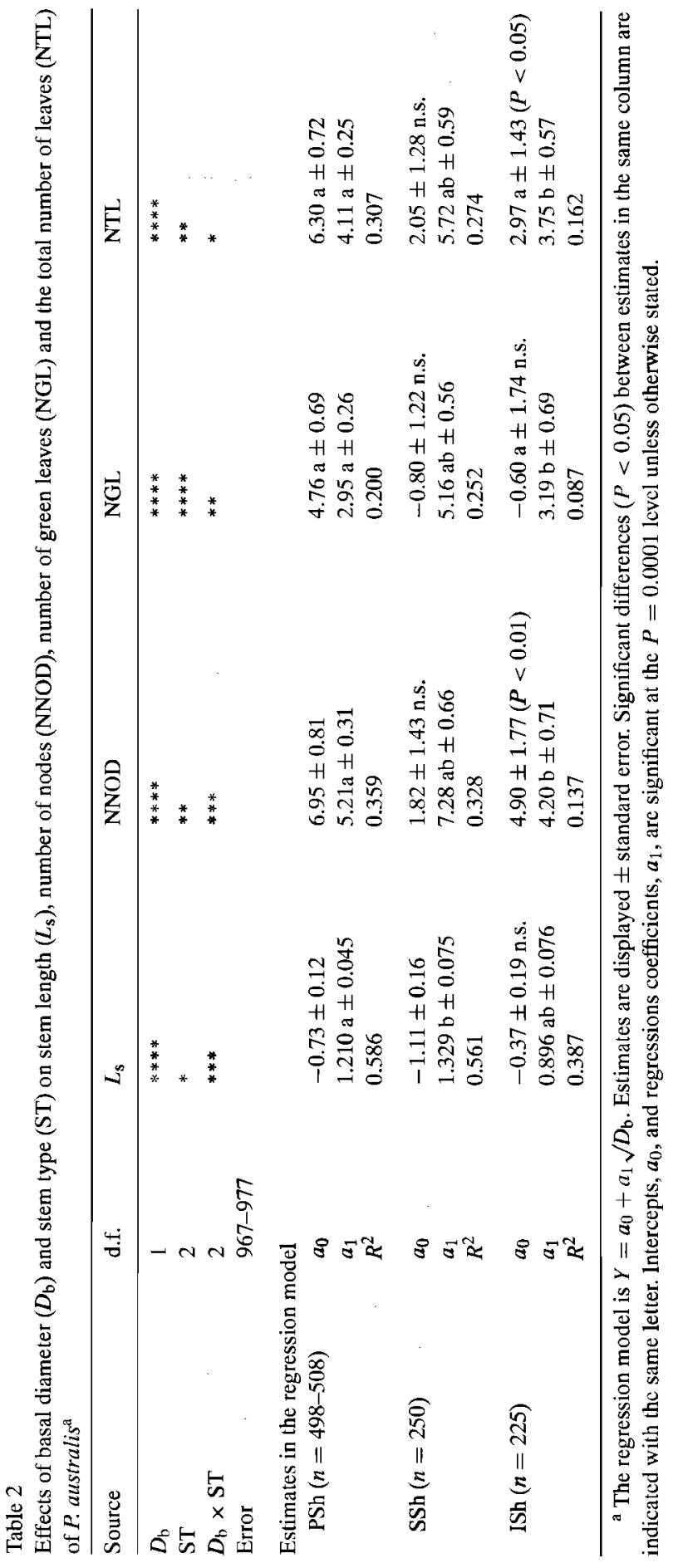



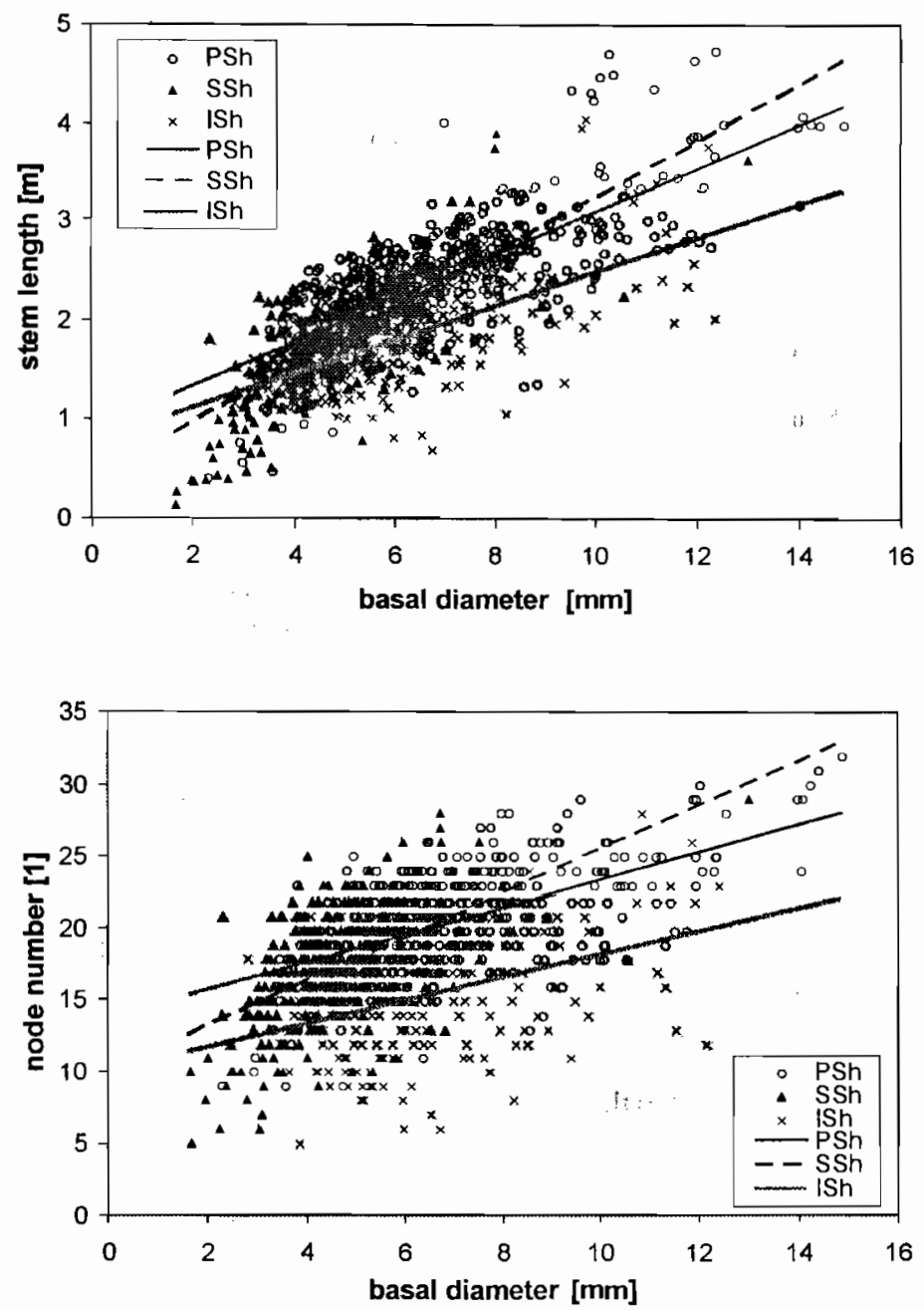

Fig. 2. Dependence of stem length $\left(L_{\mathrm{s}}\right)$ and number of nodes (NNOD) on basal diameter $\left(D_{\mathrm{b}}\right)$ and stem type of $P$. australis, ST (PSh, SSh, ISh). See Table 2 for details.

any variable indicating that neither RTI nor GEO effected the basic relationship between culm morphology traits and basal diameter.

\subsection{Effects of geographic origin and relative trophic index on culm morphology}

To evaluate the effects of GEO and RTI, the means of culm morphology traits in each stand were analyzed by two-way ANOVA. Each shoot class was analyzed separately.

Within the primary shoot class, most culm performance variables were significantly effected by GEO, not by RTI (Table 3). The only exception was the LBM/CBM ratio which 
Table 3

Effect of geographic provenance (GEO) and relative trophic index (RTI) on the culm morphology of primary shoots (PSh) of P. australis

\begin{tabular}{|c|c|c|c|c|c|c|c|c|c|}
\hline \multirow[t]{2}{*}{ Response } & \multicolumn{4}{|c|}{ Effects in ANOVA } & \multicolumn{5}{|c|}{ Estimates of the regression analysis } \\
\hline & GEO & RTI & $\begin{array}{l}\mathrm{GEO} \times \\
\text { RTI }\end{array}$ & Model & $\begin{array}{l}\text { Data } \\
\text { subset }\end{array}$ & Intercept & RTI coefficient & $R^{2}$ & Significance \\
\hline$D_{\mathrm{b}}{ }^{\mathrm{b}}$ & * & n.s. & n.s. & $* *$ & $\begin{array}{l}\text { North } \\
\text { South }\end{array}$ & $\begin{array}{l}1.810 \pm 0.026 \\
1.950 \pm 0.031\end{array}$ & $\begin{array}{l}\text { n.s. } \\
\text { n.s. }\end{array}$ & $\begin{array}{l}0.133 \\
0.000\end{array}$ & $\begin{array}{l}\text { n.s. } \\
\text { n.s. }\end{array}$ \\
\hline$L_{\mathrm{s}}$ & *** & n.s. & n.s. & ** & $\begin{array}{l}\text { North } \\
\text { South }\end{array}$ & $\begin{array}{l}2.06 \pm 0.09 \\
2.68 \pm 0.12\end{array}$ & $\begin{array}{l}0.19 \pm 0.08 \\
\text { n.s. }\end{array}$ & $\begin{array}{l}0.183 \\
0.001\end{array}$ & $\begin{array}{l}* \\
\text { n.s. }\end{array}$ \\
\hline NNOD & $* * * *$ & n.s. & n.s. & $* * * *$ & $\begin{array}{l}\text { North } \\
\text { South }\end{array}$ & $\begin{array}{l}18.52 \pm 0.51 \\
22.25 \pm 0.51\end{array}$ & $\begin{array}{l}\text { n.s. } \\
\text { n.s. }\end{array}$ & $\begin{array}{l}0.002 \\
0.023\end{array}$ & $\begin{array}{l}\text { n.s. } \\
\text { n.s. }\end{array}$ \\
\hline NLG & $* * *$ & n.s. & n.s. & ** & $\begin{array}{l}\text { North } \\
\text { South }\end{array}$ & $\begin{array}{l}11.20 \pm 0.46 \\
13.44 \pm 0.40\end{array}$ & $\begin{array}{l}\text { n.s. } \\
\text { n.s. }\end{array}$ & $\begin{array}{l}0.064 \\
0.025\end{array}$ & $\begin{array}{l}\text { n.s. } \\
\text { n.s. }\end{array}$ \\
\hline NLT & $* * *$ & n.s. & n.s. & $* *$ & $\begin{array}{l}\text { North } \\
\text { South }\end{array}$ & $\begin{array}{l}15.52 \pm 0.41 \\
18.17 \pm 0.56\end{array}$ & $\begin{array}{l}\text { n.s. } \\
\text { n.s. }\end{array}$ & $\begin{array}{l}0.095 \\
0.009\end{array}$ & $\begin{array}{l}\text { n.s. } \\
\text { n.s. }\end{array}$ \\
\hline$L_{\mathrm{s}} / D_{\mathrm{b}}$-ratio & n.s. & n.s. & n.s. & n.s. & $\begin{array}{l}\text { North } \\
\text { South }\end{array}$ & $\begin{array}{l}0.362 \pm 0.011 \\
0.346 \pm 0.013\end{array}$ & $\begin{array}{l}\text { n.s. } \\
\text { n.s. }\end{array}$ & $\begin{array}{l}0.005 \\
0.020\end{array}$ & $\begin{array}{l}\text { n.s. } \\
\text { n.s. }\end{array}$ \\
\hline $\mathrm{CBM}^{\mathrm{c}}$ & $* * * *$ & n.s. & n.s. & $* * * *$ & $\begin{array}{l}\text { North } \\
\text { South }\end{array}$ & $\begin{array}{l}1.21 \pm 0.04 \\
1.46 \pm 0.41\end{array}$ & $\begin{array}{l}0.089 \pm 0.038 \\
\text { n.s. }\end{array}$ & $\begin{array}{l}0.185 \\
\text { n.s. }\end{array}$ & $\begin{array}{l}* \\
\text { n.s. }\end{array}$ \\
\hline LBM/CBM (\%) & n.s. & $* * * *$ & n.s. & $* * * *$ & $\begin{array}{l}\text { North } \\
\text { South }\end{array}$ & $\begin{array}{l}24.6 \pm 0.8 \\
25.2 \pm 0.6\end{array}$ & $\begin{array}{l}2.86 \pm 0.69 \\
2.41 \pm 0.63\end{array}$ & $\begin{array}{l}0.418 \\
0.385\end{array}$ & $\begin{array}{l}* * * \\
* * *\end{array}$ \\
\hline
\end{tabular}

${ }^{a}$ The means of response variables for each sampling location were tested by two-way ANOVA (d.f. $=47$ for the efror), and by regression analysis for each GEO group separately ( $n$ (North) $=26, n$ (South) $=25$ ). Estimates for intercept and regression coefficient are displayed \pm standard error.

${ }^{\mathrm{b}} D_{\mathrm{b}}$ was cubic root transformed.

${ }^{\mathrm{c}} \mathrm{CBM}$ was $\log _{10}$ transformed; estimates refer to transformed variables. -

increased significantly parallel to the trophic level. Hence, the geographic origin of the location at which the reed stand grew seemed to be of greater importance than its trophic level.

The estimates of the regression analysis with RTI as an independent variable are also displayed in Table 3. The analysis was carried out separately for each GEO group. The intercept is numerically equivalent to an estimate for a sampling site with $\mathrm{RTI}=0$, i.e. a reed stand in a slightly eutrophic lake. The intercept values of all performance variables, with the exception of LBM/CBM and $L_{\mathrm{s}} / D_{\mathrm{b}}$ ratios, were significantly higher for South than for North reeds showing that culms in reed stands from south Germany, Switzerland, and Austria were thicker and longer and exhibited higher green as well as total leaf numbers than the reeds from Denmark, north and east Germany at a given trophic level.

Most regression coefficients were not significant since the two-way ANOVA failed to prove a significant RTI effect. If significant, however, a positive relation was always found. The North data subset showed a weakly significant positive correlation with RTI for basal diameter, stem length, culm biomass, and leaf/culm biomass ratio whereas no significant trend was detected in the South subset with the exception of the LBM/CBM ratio. With respect to these variables, the northern reed stands exhibited a greater (positive) response than the southern reeds to an enhanced trophic level.

Within the secondary shoot class, again the GEO effect was more important than the RTI effect since most performance variables depended on geographic provenance, but not 
Table 4

Effect of geographic provenance (GEO) and relative trophic index (RTI) on the culm morphology of secondary shoots (SSh) of P. australis ${ }^{\mathrm{a}}$

\begin{tabular}{|c|c|c|c|c|c|c|c|c|c|}
\hline \multirow[t]{2}{*}{ Response } & \multicolumn{4}{|c|}{ Effects in ANOVA } & \multicolumn{5}{|c|}{ Estimates of the regression analysis } \\
\hline & GEO & RTI & $\begin{array}{l}\text { GEO } \\
\times \text { RTI }\end{array}$ & Model & $\begin{array}{l}\text { Data } \\
\text { subset }\end{array}$ & Intercept & RTI coefficient & $R^{2}$ & Significance \\
\hline \multirow[t]{2}{*}{$D_{\mathrm{b}}{ }^{\mathrm{b}}$} & \multirow[t]{2}{*}{$* *$} & \multirow[t]{2}{*}{ n.s. } & \multirow[t]{2}{*}{ n.s. } & \multirow[t]{2}{*}{$*$} & North & $1.602 \pm 0.028$ & n.s. & 0.035 & n.s. \\
\hline & & & & & South & $1.730 \pm 0.024$ & n.s. & 0.002 & n.s. \\
\hline \multirow[t]{2}{*}{$L_{\mathrm{s}}$} & \multirow[t]{2}{*}{$* * * *$} & \multirow[t]{2}{*}{ n.s. } & \multirow[t]{2}{*}{ n.s. } & \multirow[t]{2}{*}{$* * *$} & North & $1.527 \pm 0.072$ & $0.154 \pm 0.063$ & 0.204 & * \\
\hline & & & & & South & $1.950 \pm 0.070$ & n.s. & 0.058 & n.s. \\
\hline \multirow[t]{2}{*}{ NNOD } & \multirow[t]{2}{*}{$* * * *$} & \multirow[t]{2}{*}{ n.s. } & \multirow[t]{2}{*}{ * } & \multirow[t]{2}{*}{$* * * *$} & North & $15.64 \pm 0.54$ & n.s. & 0.112 & n.s. \\
\hline & & & & & South & $19.50 \pm 0.56$ & n.s. & 0.058 & n.s. \\
\hline \multirow[t]{2}{*}{ NLG } & \multirow[t]{2}{*}{ * } & \multirow[t]{2}{*}{ n.s. } & \multirow[t]{2}{*}{ * } & \multirow[t]{2}{*}{ n.s. } & North & $9.58 \pm 0.49$ & $0.95 \pm 0.43$ & 0.167 & $*$ \\
\hline & & & & & South & $11.07 \pm 0.52$ & n.s. & 0.056 & n.s. \\
\hline \multirow[t]{2}{*}{ NLT } & \multirow[t]{2}{*}{$* *$} & \multirow[t]{2}{*}{ n.s. } & \multirow[t]{2}{*}{ n.s. } & \multirow[t]{2}{*}{$* *$} & North & $13.18 \pm 0.46$ & $1.16 \pm 0.41$ & 0.248 & $* *$ \\
\hline & & & & & South & $15.53 \pm 0.57$ & n.s. & 0.006 & n.s. \\
\hline \multirow[t]{2}{*}{$L_{\mathrm{s}} / D_{\mathrm{b}}$-ratio } & \multirow[t]{2}{*}{ n.s. } & \multirow[t]{2}{*}{ n.s. } & \multirow[t]{2}{*}{ n.s. } & \multirow[t]{2}{*}{ * } & North & $0.350 \pm 0.016$ & $0.036 \pm 0.014$ & 0.211 & $*$ \\
\hline & & & & & South & $0.390 \pm 0.014$ & n.s. & 0.000 & n.s. \\
\hline \multirow[t]{2}{*}{$\mathrm{CBM}^{\mathrm{c}}$} & \multirow[t]{2}{*}{$* * * *$} & n.s. & n.s. & $* *$ & North & $2.46 \pm 0.15$ & n.s. & 0.108 & n.s. \\
\hline & & & & & South & $3.34 \pm 0.15$ & n.s. & 0.001 & n.s. \\
\hline LBM/CBM (\%) & n.s. & $* * * *$ & n.s. & $* * *$ & North & $27.6 \pm 1.3$ & $4.9 \pm 1.2$ & 0.431 & $* * *$ \\
\hline & & & & & South & $30.8 \pm 1.4$ & n.s. & 0.156 & n.s. \\
\hline
\end{tabular}

a See Table 3 for explanations.

${ }^{b} D_{\mathrm{b}}$ was cubic root transformed.

${ }^{c} \mathrm{CBM}$ was square root transformed; estimates refer to transformed variables.

on the trophic level. The LBM/CBM ratio was the only exception (Table 4). There were, however, significant GEO $\times$ RTI interactions for node number NNOD and green leaf number NGL indicating that the relation between these variables and RTI depended on geographic origin. The regression analysis showed lower intercept estimates for the North reeds for all variables. This means, that the north reeds had a weaker performance at the RTI $=0$ level. If significant, the regression coefficients showed a positive relation between stem length, number of nodes, green and total leaf number, LBM/CBM ratio and RTI. In all these cases, the North reeds exhibited a stronger response to the trophic level, i.e. a higher regression coefficient, than the South reeds.

Essentially, the same results were yielded in the insect infested shoot class (Table 5). There was a pronounced GEO effect. Only in NNOD and LBM/CBM ratio was a significant RTI effect detected, but without significant GEO $\times$ RTI interactions. The regression analysis proved that there was no response to RTI in each data subset except for the relative leaf biomass, which increased in parallel with the trophic level.

\section{Discussion}

This paper aimed to find out general effects of eutrophication and excess nutrient supply on the culm morphology of Phragmites reeds. The approach was a field survey on 51 stands at 41 selected lakes and 10 waste water and sludge treatment plants of known trophic status 
Table 5

Effect of geographic provenance (GEO) and relative trophic index (RTI) on the culm morphology of insect infested shoots (ISH) of P. australis ${ }^{\mathrm{a}}$

\begin{tabular}{|c|c|c|c|c|c|c|c|c|c|}
\hline \multirow[t]{2}{*}{ Responses } & \multicolumn{4}{|c|}{ Effects in ANOVA } & \multicolumn{5}{|c|}{ Estimates of the regression analysis } \\
\hline & GEO & RTI & $\begin{array}{l}\text { GEO } \\
\times \text { RTI }\end{array}$ & Model & $\begin{array}{l}\text { Data } \\
\text { subset }\end{array}$ & Intercept & $\begin{array}{l}\text { RTI } \\
\text { coefficient }\end{array}$ & $R^{2}$ & Significance \\
\hline \multirow[t]{2}{*}{$D_{\mathrm{b}}{ }^{\mathrm{b}}$} & * & n.s. & n.s. & n.s. & North & $1.700 \pm 0.023$ & n.s. & 0.062 & n.s. \\
\hline & & & & & South & $1.872 \pm 0.030$ & n.s. & 0.003 & n.s. \\
\hline \multirow[t]{2}{*}{$L_{\mathrm{s}}$} & $* *$ & n.s. & n.s. & $* *$ & North & $1.623 \pm 0.077$ & n.s. & 0.012 & n.s. \\
\hline & & & & & South & $1.961 \pm 0.060$ & n.s. & 0.043 & n.s. \\
\hline \multirow[t]{2}{*}{ NNOD } & $* * * *$ & * & n.s. & $* * * *$ & North & $13.12 \pm 0.43$ & n.s. & 0.064 & n.s. \\
\hline & & & & & South & $17.38 \pm 0.53$ & n.s. & 0.130 & n.s. \\
\hline \multirow[t]{2}{*}{ NLG } & $* * * *$ & n.s. & n.s. & $* * * *$ & North & $5.17 \pm 0.60$ & n.s. & 0.064 & n.s. \\
\hline & & & & & South & $8.93 \pm 0.52$ & n.s. & 0.111 & n.s. \\
\hline \multirow[t]{2}{*}{ NLT } & $* * * *$ & n.s. & n.s. & $* * * *$ & North & $10.24 \pm 0.47$ & n.s. & 0.012 & n.s. \\
\hline & & & & & South & $13.89 \pm 0.40$ & n.s. & 0.027 & n.s \\
\hline \multirow[t]{2}{*}{$L_{\mathrm{s}} / D_{\mathrm{b}}$-ratio } & n.s. & n.s. & n.s. & n.s. & North & $0.287 \pm 0.012$ & n.s. & 0.004 & n.s. \\
\hline & & & & & South & $0.310 \pm 0.011$ & n.s. & 0.036 & n.s. \\
\hline \multirow[t]{2}{*}{$\mathrm{CBM}^{\mathrm{c}}$} & $* *$ & n.s. & n.s. & $*$ & North & $1.069 \pm 0.037$ & n.s. & 0.063 & n.s. \\
\hline & & & & & South & $1.256 \pm 0.044$ & n.s. & 0.006 & n.s. \\
\hline \multirow[t]{2}{*}{$\operatorname{LBM} / \mathrm{CBM}(\%)$} & * & $* * *$ & n.s. & ** & North & $22.9 \pm 1.2$ & $2.7 \pm 1.0$ & 0.269 & $*$ \\
\hline & & & & & South & $26.5 \pm 0.9$ & $2.4 \pm 1.0$ & 0.213 & * \\
\hline
\end{tabular}

${ }^{a}$ See Table 3 for explanations.

${ }^{\mathrm{b}} D_{\mathrm{b}}$ was cubic root transformed.

${ }^{\mathrm{c}} \mathrm{CBM}$ was square root transformed; estimates refer to transformed variables.

(Appendix). About eight culm performance variables were investigated. The means differ significantly among culm classes demonstrating that the flowering 'primary shoots' (PSh) are the 'optimal' culm class with taller stems, more leaves and higher numbers of nodes than the flowerless replacement or 'secondary shoots' (SSh) and the polygenetic 'insect infested shoots' (ISh). These basic shoot classes have been proved to differ in most morphological, anatomical and growth features which have been investigated so far (Haslam, 1969; Ostendorp, 1995, 1999; Ostendorp and Möller, 1991). Hence, they were treated separately in this study.

The independent variables are the geographic position of the sampling location (GEO) discriminating a North and a South data subset and the 'relative trophic index' (RTI) which allows to express the trophic level in a continuous scale. The definition of trophy in this study follows the terminology used in limnology, which primarily refers to the nutrient concentrations in the pelagic water as a background of pelagic net primary production and as a cause of eutrophication (Wetzel, 1983; Schwoerbel, 1993). The main advantage of the RTI is that it connects the conventional trophic scale (see Vollenweider, 1971; LAWA, 1998) with the saprotrophic load in artificial wetlands, for which no trophic category is defined. The RTI can be regarded as a ranking variable describing the relative positions of the sampling locations along the trophic axis, irrespective of the composition of the data set. It also reflects the trophic distance between any two locations in the data set when its composition is held constant, as it is the case in this study. This, however, will not hold true, if one or more cases are removed from or added to the data set. 
Allometric relations are often used in growth analysis to estimate the individual biomass of plants (Květ, 1971; Šesták et al., 1971; Hunt, 1978). In Phragmites, mainly the basal diameter and/or the culm length have been used (Szczepanská and Szczepanski, 1976; Ho, 1979; Kauppi et al., 1983; Dinka, 1986; Granéli, 1987; Ostendorp, 1988; Coops et al., 1991; Schieferstein, 1997). The correlation coefficients in these studies are usually high $\left(0.75<R^{2}<0.98\right)$ depending on the model applied (linear, exponential) and the number of independent variables (diameter or height, or both). The model presented in this paper bases on stem height and basal diameter. The correlation coefficient $\left(0.87<R^{2}<0.92\right.$ depending on shoot class) is higher than in most of the models proposed in the literature. No clear-cut influence of RTI and GEO on the shape of the regression curves was found. Therefore, it is concluded, that they can be universally used since the data basis covered a wide range of lake types and ecological conditions.

Most culm morphology traits are affected by the geographic origin in each culm class and not by the trophic level. The ratio of stem length/basal diameter $\left(L_{\mathrm{s}} / D_{\mathrm{b}}\right)$ is not effected by any factor. However, the percentage of leaf biomass (LBM/CBM) is influenced by the RTI only.

Estimates have been calculated for each variable for a stand of medium trophic level, i.e. for a slightly eutrophic lake with RTI $=0$. These estimates are significantly higher in the southern than in northern reed stands in respect to all culm classes except for $L_{\mathrm{s}} / D_{\mathrm{b}}$ and LBM/CBM ratios (Tables 3-5). Generally, reed culms from stands in southern Germany, Switzerland and Austria are stouter exhibiting higher numbers of nodes and leaves and a higher biomass than those from northern Germany and Denmark.

When the geographic groups are analyzed separately no significant correlations with RTI can be detected in the South group in any culm class, with the exception of the LBM/CBM ratio. In the North group, however, many morphology variables are positively correlated with the trophic level at least in one culm class. Here, the primary shoots are thicker, longer, and exhibit a greater biomass when exposed to higher trophic levels (Table 3 ). In the secondary shoot class, stem height, total number of leaves, and number of green leaves are the most effected (Table 4). The insect infested shoots are the least effected, presumably because the type of parasitic damage superimposes the trophic influence. These results show clearly that culms from northern reeds reveal a marked response to the trophic situation, whereas the southern do not. This response is always positive.

The mean LBM/CBM ratio is the only feature that shows a clear-cut dependence on RTI in both geographic groups for all culm classes. It is well known that Phragmites culms of a given total biomass consist of constant proportions of stem, leaf sheath and leaf biomass (Mook and van der Toorn, 1982; Ostendorp, 1988). Regarding single shoots, the percentage of leaf biomass is negatively correlated with the total culm biomass, which is expressed by the negative quadratic term in the no-intercept model depicted in Eq. (3) (see also Eqs. (8-10). This means that stouter culms have to invest more resources into stem axis, and less organic carbon into photosynthetic organs than smaller culms. On the basis of means from 51 stands, the LBM/CBM does not significantly correlate with CBM $\left(R^{2}=0.025\right.$ ) but is significantly positive related to the RTI (Tables $3-5$ ). One may speculate that stands under poly- and saprotrophic conditions may have an advantage compared to oligo- and mesotrophic reeds in terms of light harvesting and carbon allocation efficiency. 
The results of this study support the hypothesis that the trophic level may influence the culm architecture of Phragmites reeds. Nevertheless, the two-way ANOVA reveals a much stronger influence of the geographic region, i.e. northern reeds show a positive response to the trophic level for many variables, - southern reeds do not. Three reasons may stand behind this discrepancy

- climatic effects: mean temperatures, number of clear days (cloud cover $<20 \%$ ) and number of summer days $\left(T_{\max }>25^{\circ} \mathrm{C}\right.$ ) during summer are higher in southern locations (Ostendorp, unpublished data), so that nutrient scarcity may be overwhelmed in the south;

- geochemistry of lake water and sediments: in northern Germany and Denmark, the investigated oligo- and mesotrophic lakes are relatively low in calcium, and the littoral sediments are sandy, whereas lakes in the alpine foreland are alkaline and the substrates mostly consist of calcium carbonate rich sands or muds;

- trophic history of the lakes: some of the oligotrophic and mesotrophic lakes from the southern data set had been eutrophic from the 1960s to the $1980 \mathrm{~s}$, but have been subjected to water quality improvement measures since about 20 years. In northern Germany and Denmark, however, all oligotrophic and mesotrophic lakes considered in this study have kept on their trophic state as long as available data go back. Hence, the culm morphology traits may reflect the historical nutrient status instead of the present status of re-oligotrophication.

Additionally, genetic differences between northern and southern clones which may express themselves in stouter culms under nutrient poor conditions cannot be ruled out.

It was hypothesized that Phragmites reeds undergo stand structure modification during the process of lake eutrophication which may finally lead to a die-back (e.g. Klötzli, 1971; Schröder, 1979, 1987). This concept cannot be supported by the results of this study. The independence or even the positive dependence of performance variables on RTI cannot be interpreted as signs of degradation: it is not convincing to argue that the side effects of eutrophication which have been made responsible for reed die-back (e.g. increase in organic matter, anaerobic decomposition processes and accumulation of toxic compounds in the sediment, etc.) lead to a reed die-back and in the same way to an increase in vitality, as have been shown in this study. Additionally, no signs of stand structure deterioration or thinning of density have been observed in the vicinity of the sampling locations. It is concluded therefore, that there is no general relation between eutrophication and reed die-back. However, if there were a relation, it should lie far back in the past, so that the current reed stands have equilibrated to the new trophic conditions or it should be restricted to very special situations where additional stressors occur which then should not be correlated with the trophic level.

\section{Acknowledgements}

We wish to thank all persons and institutions who or which contributed considerably to this study by placing unpublished data at our disposal. We also appreciate the help of Willi Nagl, Statistical Services, University of Konstanz for many helpful comments and Katja Schmidt for linguistic improvements. This study was funded by the Environment and Climate Program of the European Commission, contract no. ENV4-CT95-0147 (EUREED II). 


\section{Appendix}

List of sampling locations (name of the lake or constructed wetland (CW), country (and federal state, if located in Germany), geographic position (WGS84 datum), relative trophic index (RTI), trophic category see Vollenweider (1971); LAWA (1998)

\begin{tabular}{|c|c|c|c|c|c|}
\hline Name & Country & $\begin{array}{l}\text { Longitude } \\
\left({ }^{\circ} \mathrm{E}\right)\end{array}$ & $\begin{array}{l}\text { Latitude } \\
\left({ }^{\circ} \mathrm{N}\right)\end{array}$ & RTI & Trophic category \\
\hline North data subset & & & W & & \\
\hline Großer Stechlinsee & D: BB & 13.0167 & 53.1531 & -1.50 & Oligotrophic \\
\hline Großer Wummsee & D: BB & 12.8074 & 53.1881 & -1.17 & Oligotrophic \\
\hline Almind Sø & DK & 9.5408 & 56.1502 & -0.91 & Oligo-/mesotrophic \\
\hline Ihlsee & D: SH & 10.2910 & 53.9540 & -0.71 & Mesotrophic \\
\hline Selenter See & $\mathrm{D}: \mathrm{SH}$ & 10.5031 & 54.2911 & -0.68 & Mesotrophic \\
\hline Nors Sø & DK & 8.5873 & 57.0360 & -0.54 & Mesotrophic \\
\hline Vandet $S \varnothing$ & DK & 8.5367 & 56.0053 & -0.41 & Mesotrophic \\
\hline Hampen $\mathrm{S} \emptyset$ & DK & 9.3748 & 56.0192 & -0.40 & Mesotrophic \\
\hline Madum Sø & DK & 9.9210 & 56.8057 & -0.37 & Mesotrophic \\
\hline Breiter Luzin & $\mathrm{D}: \mathrm{MV}$ & 13.4830 & 53.3655 & -0.14 & Mesotrophic \\
\hline Krakower See & D: MV & 12.3029 & 53.6378 & -0.06 & Eutrophic \\
\hline $\begin{array}{l}\text { Schaalsee- } \\
\text { Techiner See }\end{array}$ & $\begin{array}{l}\mathrm{D}: \mathrm{SH} \\
+\mathrm{MV}\end{array}$ & 10.9542 & 53.5728 & 0.02 & Eutrophic \\
\hline $\begin{array}{l}\text { Schaalsee-Bernsttorffer } \\
\text { Binnensee }\end{array}$ & $\begin{array}{l}\text { D: SH } \\
+\mathrm{MV}\end{array}$ & 10.9502 & 53.6248 & 0.14 & Eutrophic \\
\hline Dobersdorfer See & D: SH & 10.3215 & 54.3179 & 0.23 & Eutrophic \\
\hline Sarnekower See & D: SH & 10.7506 & 53.5 & 0.23 & Eutrophic \\
\hline Cantnitzer See & D: MV & 13.3890 & 52.3707 & 0.51 & Eutrophic \\
\hline Lanker See & D: SH & 10.3048 & 54.2001 & 0.83 & Eu-/hypertrophic \\
\hline Zwischenahner Meer & $\mathrm{D}: \mathrm{NS}$ & 8.0027 & 52.4728 & 0.96 & Poly-/hypertrophic \\
\hline Steinhuder Meer & D: NS & 9.3748 & 52.4728 & 1.19 & Poly-/hypertrophic \\
\hline Redingsdorfer See & D: SH & 10.7178 & 54.1033 & 1.28 & Poly-/hypertrophic \\
\hline Dümmer & D: NS & 8.3568 & 52.5068 & 1.34 & Poly-/hypertrophic \\
\hline CW Weiperfelden & D: HE & 8.5507 & 50.4170 & 1.36 & Saprotrophic \\
\hline CW Thalfang & $\mathrm{D}: \mathrm{RP}$ & 6.9930 & 49.7409 & 1.69 & Saprotrophic \\
\hline CW Othfresen & D: NS & 10.3890 & 52.0045 & 1.99 & Saprotrophic \\
\hline $\begin{array}{l}\text { CW Hof Möhr } \\
\text { (Schneverdingen) }\end{array}$ & D: NS & 9.8509 & 53.0912 & 2.29 & Saprotrophic \\
\hline CW Wiltingen & $\mathrm{D}: \mathrm{RP}$ & 6.5882 & 49.6661 & 2.41 & Saprotrophic \\
\hline \multicolumn{6}{|l|}{ South data subset } \\
\hline Starnberger See & D: BAY & 11.2697 & 47.8860 & -1.23 & Oligo-/mesotrophic \\
\hline Fuschl See & $\mathrm{AU}$ & 13.2508 & 47.8075 & -1.08 & Oligotrophic \\
\hline $\begin{array}{l}\text { Bodensee- } \\
\text { Überlinger See }\end{array}$ & D: BW & 9.1740 & 47.7217 & -1.02 & Mesotrophic \\
\hline
\end{tabular}




\begin{tabular}{llrrrl} 
Wörthsee & D: BAY & 11.1700 & 48.0556 & -1.02 & Oligotrophic \\
Zürichsee-Obersee & CH & 8.9002 & 47.2326 & -0.72 & Oligo-/mesotrophic \\
Ammersee & D: BAY & 11.0922 & 48.0256 & -0.71 & Mesotrophic \\
Bodensee-Untersee & D: BW & 9.0835 & 47.6872 & -0.67 & Mesotrophic \\
Mattsee & AU & 13.1342 & 47.9877 & -0.65 & Oligo-/mesotrophic \\
Bannwaldsee & D: BAY & 10.7589 & 47.5900 & -0.54 & Mesotrophic \\
Chiemsee & D: BAY & 12.4395 & 47.9183 & -0.51 & Mesotrophic \\
Wallersee & AU & 13.1873 & 47.9218 & -0.47 & Mesotrophic \\
Zuger See & CH & 8.5169 & 47.1659 & -0.39 & Mesotrophic \\
Mindelsee & D: BW & 9.0070 & 47.7532 & -0.39 & Mesotrophic \\
Waginger See & D: BAY & 12.8010 & 47.9182 & -0.02 & Eutrophic \\
Schliersee & D: BAY & 11.8533 & 47.7245 & 0.02 & Eutrophic \\
Schleinsee & D: BW & 9.6263 & 47.6070 & 0.20 & Eutrophic \\
Hopfensee & D: BAY & 10.6723 & 47.5914 & 0.56 & Eutrophic \\
Kißlegger Obersee & D: BW & 9.8754 & 47.8015 & 0.80 & Poly-/hypertrophic \\
CW Gangkofen & D: BAY & 12.5830 & 48.4158 & 0.92 & Saprotrophic \\
Zeller See b. Kißlegg & D: BW & 9.8737 & 47.7855 & 0.99 & Poly-/hypertrophic \\
Federsee & D: BW & 9.6183 & 48.0751 & 1.06 & Poly-/hypertrophic \\
CW Groß-Rohrheim & D: HE & 8.4671 & 49.7173 & 1.41 & Saprotrophic \\
CW Happburg & D: BAY & 11.5498 & 49.4323 & 1.61 & Saprotrophic \\
CW Olching & D: BAY & 10.9999 & 48.2491 & 1.85 & Saprotrophic \\
CW Velden/Vis & D: BAY & 12.2664 & 48.3491 & 1.93 & Saprotrophic \\
\hline
\end{tabular}

\section{References}

Brix, H., 1999a. The European Research Program on reed die-back and progression (EUREED). 1n: Grosser, St., Küh1, H. (Eds.), Reed bed - importance of a plant community in ecology and technology. Limnologica, Vol. 29 , pp. 5-10.

Brix, H., 1999b. Genetic diversity, ecophysiology and growth dynamics of reed (Phragmites australis). Aquat. Bot. 64, 179-184.

Coops, H., Boeters, R., Smit, H., 1991. Direct and indirect effects of wave attack on helophytes. Aquat. Bot. 41, 333-352.

Dinka, M., 1986. The effect of mineral nutrient enrichment of Lake Balaton on the common reed (Phragmites australis). Folia Geobot. Phytotax. 21, 65-84.

Granéli, W., 1987. Shoot density regulation in stands of reed. P. australis (Cav.) Trin. Arch. Hydrobiol. Beih. 27, 211-222.

Haslam, S.M., 1969. Stem types of $P$. communis. Ann. Bot. 33, 127-131.

Ho, Y.B., 1979. Shoot development and production studies of Phragmites australis (Cav.) Trin. ex Steudel in Scottish lochs. Hydrobiologia 64, 215-222.

Hunt, R., 1978. Plant Growth Analysis. Studies in Biology, Vol. 96. E. Amold Publication, London

Kauppi, P., Selkäinaho, J., Puttonen, P., 1983. A method for estimating aboveground biomass in Phragmites stands. Ann. Bot. Fenn. 20, 51-55.

Klötzli, F., 1971. Biogenous influence on aquatic macrophytes especially Phragmites communis. Hidrobiologia (Bucaresti) 12, 107-111.

Kvĕt, J., 1971. Growth analysis approach to the production ecology of reedswamp. Hidrobiologia (Bucaresti) 12 , $15-40$.

Länderarbeitsgemeinschaft Wasser (LAWA), 1998. Gewässerbewertung — stehende Gewässer. Richtlinie für die Bewertung nach trophischen Kriterien. Berlin, p. 60. 
Mook, J.H., van der Toorn, J., 1982. The influence of environmental factors and management on stands of Phragmites australis. Part II. Effects on yield and its relationship with shoot density. J. Appl. Ecol. 19, 501-517.

Ostendorp, W., 1988. Der Einfluß von Winterschnitt und-brand auf die Bestandsstruktur von Seeufer-Schilfröhrichten am Bodensee-Untersee. Ph.D. Thesis, University of Freiburg i. Br. (Germ.), p. 208.

Ostendorp, W., 1989. Die-back of reeds in Europe - a critical review of literature. Aquat. Bot. 35, 5-26.

Ostendorp, W., 1995. Effect of management on the mechanical stability of lakeside reeds in Lake Constance. Acta Oecol. 16, 277-294.

Ostendorp, W., 1999. Management impacts on stand structure of lakeshore Phragmites reeds. Intern. Rev. Ges. Hydrobiol. 84, 33-47.

Ostendorp, W., Möller, J., 1991. EM-algorithm as a tool for structure analysis of stands of the common reed (Phragmites australis). Ecol. Model. 53, 27-38.

Schieferstein, B., 1997. Ökologische und molekularbiologische Untersuchungen an Schilf (Phragmites australis (Cav.) Trin. ex Steudel) im Bereich der Bornhöveder Seenkette. EcoSys (Suppl. 22). Kiel.

Schröder, R., 1979. The decline of reed swamps in Lake Constance. Symp. Biol. Hung. 19, 43-48.

Schröder, R., 1987. Das Schilfsterben am Bodensee-Untersee. Beobachtungen, Untersuchungen und Gegenmaßnahmen. Arch. Hydrobiol. Suppl. 76, 53-99.

Schwoerbel, J., 1993. In: G. Fischer, (Ed.), 7th edn., Einführung in die Limnologie. Stuttgart, 2, p. 387.

Šesták, Z., Catský, J., Jarvis, P.G., 1971. Plant Photosynthetic Production. Den Haag.

Szczepanská, W., Szczepanski, A., 1976. Typha latifolia L. and Typha angustifolia L. in relation to fertility of soils. Pol. Arch. Hydrobiol 23, 233-248.

Van der Putten, W.H., 1994. Assessing ecological change in European wetlands: how to know what parameters should be monitored to evaluate the die-back of common reed (Phragmites australis)? In: Aubrecht, G., Dick, G., Prentice, C. (Eds.), Monitoring Ecological Change in Wetlands of Middle Europe, Vol. 31. Stapfia, Linz, pp. 61-68.

Vollenweider, R., 1971. Scientific fundamentals of the eutrophication of lakes and flowing waters, with particular reference to nitrogen and phosphorus as factors in eutrophication. OECD Report, Paris, p. 159.

Wetzel, R.G., 1983. Limnology, 2nd Edition. Saunders, Philadelphia. 